\title{
Governing the Street Space Contestation and Conflict Through the Empowerment of Indigenous Community in Bali- Indonesia
}

\author{
Antonius Karel Muktiwibowo \\ 2nd-year PhD Student \\ School of Architecture Planning and Landscape \\ Newcastle University - United Kingdom \\ Email:a.k.muktiwibowo@ncl.ac.uk
}

\section{Doi:10.5901/mjss.2013.v4n9p56}

\begin{abstract}
Nowadays, the city is challenged by more complex problems in the economic, social, cultural and political sector. One of the problems reflected on scarcity of urban space in correlation with unbalanced population growth, uncontrolled urban street vendor, limited resources, and environmental degradation. The top-down governance approach often encounter difficulties in directing social movement in accordance with recent policies by rejection or inability to manage communities then the social conflict is potentially arisen. It is reflected in the increased tension of space contestation on street space following its economic value. A Street has been commodified or commercialized as a privatized rental space for parking, street vendor and other individual activities. Thus, who has the authority to exploit economical gain towards the street as public space? Is it private sector, community, or municipality? Who will manage the actors who control a certain segment of the street? Who will gain the lost and advantage and guarantee that its justice? It will definitely need an active actor who capable to apply good governance and justice in street space contestation, when the local municipality with its fix, passive and procedural administrative difficult to manage street activities. In this paper, the role of Bali's indigenous community is evaluated in relation with its unique capability to control street space in their territory. With its local wisdom, active communication and cooperation to all urban actors, coordination and leadership can contribute a positive result in street activity management and minimizing horizontal conflict.
\end{abstract}

Keywords: Street, contestation, indigenous community, control

\section{Social conflict on the street space}

Denpasar street has been used and contested from traffic, car and motor cycled parking, individual contemporary storage, street vendors, social and religious ceremonial space, political and economic space. It creates an ambiguity of street function and community activity's order expressed in street chaos like the pedestrian who walking in the middle of the street because the sidewalk is being used as vendors stall or motorcycle parking space and in other cases, half width of street has been used for car parking, wedding or funeral ceremonial space, and also often being used as a building material temporary storage. Conflict as a form of disagreement over different perspectives of the right to use the street space often produce tension between various groups (Madanipour, 2010). Madanipour (1996) also argues that these irregular people behaviour defines conflict, create unusual activities (Geertz, 1993) that should not be conducted in certain space as a result of human behaviour that often differ because of their personal needs and interest (Ritzer, 2005). People differences in personal uses of street space have been indicated by Fink (1968) as an 'antagonistic interaction', a systematic character of conflict. While managing interaction among people is not a simple matter as it is related with various actor backgrounds, way of communication (Luhmann, 1995) and different perspectives over specific space that has different material and immaterial values. This complexity of conflict has created a big challenge in community governance in regard to manage conflict, which should carefully outline its definition and justify each conflict in fair consideration of its negative and positive impacts.

The negative impacts of conflict are community disintegration, personal discomfort, group domination and social material and immaterial cost. Disintegration or the division of specific individuals or groups from their main community is mainly caused by the internal and external factor. External factor means that disintegration is resulted from the external factor outside the setting of space such as outsider or actor outside communities trying to take control of street space with its related economic resources outside from local communities right, for example the presence of 'new-comer' security or parking man regulator, new investor ,or external 'political' actor who has an intention to disintegrate certain communities for specific interests, which often happened in Denpasar. The other internal factor relates with internal 
member competition towards the distribution of resources and different perspective towards equality and justice over material and immaterial subdivision. Both internal and external factor of community disintegration usually lead to personal discomfort. With the previous conflict or inherited social conflict, an individual member will suffer personal inconvenience level while gathering with people in the range of dispute. This behaviour is expressed in the place preference of vendors for specific street space to hang out which inevitably create small group of actors with certain territorialisation zoning that share the similar psychological and emotional intimacy. When the individual grouping of similarities becomes larger it will express a certain domination of group over the minority one as happened to the case eleven 'Pasar Sanglah' street occupation when zoning of street trader often directed by domination of similar activities and actor relationship. When certain length street is being dominated for motorcycled parking area with a specific 'ethnic' group control then another 'new' parking controller will be difficult to replace them. It is also happened with group of vendor relationship that dominant in a certain area that resistant to other new vendor to use street space, especially when the 'new user' characteristic such as ethnicity and language are distinctive that create difficulties for maintain balance interaction with the dominant group.

While negative impacts of conflict often are considered to be minimized, it must be valued that conflict also bring a positive influence to2 community such as enhancing community solidarity, positive and creative transformation and individual and group quality development. In Denpasar the expression of territoriality belongings is quite high, which is expressed through its built environment such as 'Banjar' community meeting place and their Temple that represent both identity and dignity therefore maintenance and renovation of 'public' community building always become first priority in community budgeting. Apart from visual evidence of territorialisation through architecture manifestation, it is influenced to the social everyday life, that the comprehension of indigenous community dominant right towards space, especially public space still unchangeable. The sense of Balinese community is noticeable when a religious and social community ceremony being held in certain length of street where the indigenous community will gather around the street and collaborate together to use and modify the street for their private communal intentions. This behaviour is not only expressing the sense of space territoriality, but furthermore, into an expression of domination of space and power to be other minor conflicting communities. When a religious ceremony being held on the street and traffic directed by 'Pecalang' community regulator, then the common 'small' friction is happened between the ordinary commuter and Pecalang, arguing the right to trespass and use the public street. When this case happened, other community members will support their regulator, by group and face the intruder together as a bulk group of people against the conflicting agents. It is conducted similarly when the indigenous wants to control resident's legality in their territory, then the solidarity of indigenous commonality will enlarge to demonstrate the 'real' community that has the power over space.

In addition with this solidarity behaviour against the conflicting agents, it is significantly affecting community transformation. This community transformation is created from experienced gained through the conflict interaction. As witnessed in 'Paruman' or Balinese community meeting it is shown that there is no absolute agreement on the community decision especially dealing with conflict resolution. When there is one statement for conflict solution being stated, there are still a group or individuals who disagree with the statement. For example, in community initiated migrant control in Desa Pakraman Sesetan (Sesetan Village), when there is one statement about the objection of nonBalinese user or Street Vendor on a certain street, there is another group or individual who has an opposite action towards community action because of their personal relation with non-Balinese actor or there is another economic interest. This contradiction and discussion for conflict solution produce another updated norm which is called 'Perarem' which suggest that the original norm of Balinese community call 'Awig-awig' has been added and updated into new transformed regulation that coherent with recent community condition and problems. Therefore, the existence of conflict can contribute positive community's transformation, not only related with external factor such as migrant intrusion in Balinese setting as an effect of space commodification, the intern conflicts such as caste, age, idea and power differences over certain community policy or resource's distribution are developing community structure, norm and regulation to better stage that adaptable to the urban continuous change.

Social Conflict as a result of competition, difference, contradictory communication (Luhmann, 1995) over material and immaterial resources will generate a new transformed community based on its responses to negative and positive impact of conflict. In Denpasar street setting with various actors and activity, conflict will move further than the competition over territorial gain, but it also recreates community identity as well as redefinition of the community opponents (Gebrewold-Tochalo, 2009), as indicated by transformation of resident acceptance from Hindus-Balinese people that moderately accepted another resident with different character. Community is transformed followed by the dynamic dimension of community conflict, which requires complex understanding and integration from many factors, especially in Indonesia that Indonesia consists of 656 tribes with six main religions (Sopandi, 2012). This plurality of 
community identity often shape conflict between different communities which is known in Indonesian term as SARA conflict ( social conflict based on tribes, religion, race, and social class differences). Similarly, in public space such as street, the conflict arises commonly between user and resident in controlling and maintaining social interaction influenced by gender, age, group and culture (Madanipour, 2010) as a result of contestation between exchange and use value of street space (Madanipour, 2007). Besides all various factors that triggered conflict, it has blurred identification, whether a certain conflict is individual or group based one, as frequently a social group conflict is derived from individual difference, which enlarges to a group conflict as a matter of social group cohesion or SARA issues, which will further be discussed in the following part related to the factors that create social conflict on the street.

\section{The factors of Denpasar's street Social conflict}

Street conflict management is a complex and interrelated issue caused by various differences in economy, social, politic, culture, race, gender, ethnic, religion and other matter, which can cause preference distinctions. With the plurality and heterogenic actors on Denpasar street, the local municipality often confronts some difficulties to construct a certain agreeable common will for harmonious community, especially regarding the one who has authority to occupy, govern and maintain street between local indigenous community, street user and municipality and create a sense of justice in resource's distribution without considering actors background differences as mentioned in previous section; SARA (race, ethnic, religion, class). When the justification of conflict factors is clear then a suitable solution to reduce or manage conflict will be more effective and efficient.

A differences often lead to racism, which believes a certain domination and superiority of an ethnic group over the other. Denpasar community define Race more into genetic difference such us Chinese, Western, and local (domestic) people while ethnic determine people based from geographic origin indicated by language accent beside physical appearance. Positioned as indigenous inhabitant, Balinese dominancy over other race indicated in their different response of interaction especially economic one. Based on interview with several Balinese people, it is revealed that Chinese tribe categorized as trader and major business investor owning or leasing most store along Denpasar major street. This tribe can be categorized as problematic exclusive actors, as they inhabit in Balinese territory but with less and passive contribution to community. With a background as a migrant from outside Bali, they force the value, norm and equality principle as Indonesian citizen to disrespect the local community norm except economic and social sanctions of indigenous norm are powerful enough to direct them. Different Chinese's understanding to indigenous activities that block access or occupy the street along the street can create small friction relates to the right of street accessibility and the effect to their business, but with Chinese actor's understanding to indigenous value, this potential disagreement can be solved; however, this understanding is not applied to all Chinese residents. Therefore, a certain local force is still required. Other races that occasionally create community conflict are western or non-Asian race that commonly treated as tourist-visitor, an outsider but unaware of the value of 'sacred' place or occasion, for example when Balinese community conducted a religious ceremony, the 'tourist' race considers it as a tourist object then starts documenting the session with inappropriate dress or not realizing that they are standing in a sacred place which can be categorized by community as tradition values offences. The common dispute about the right of outsider presence in a certain place or ceremony still become a hot debate among community, especially the exclusive one.

The ethnicity difference is a more complicated conflict factor to be solved. The complexity of ethnicity is resulted from the ambiguity of 'equality' meaning for Indonesian citizen. When the race difference relates tightly with minority, it is not applied similarly with ethnic, as Balinese categorized them as 'Tamiu', a resident who has a different right of street resources and obligation to their area. This comprehension of the content of Balinese traditional norm has been utilized as the de-facto legality of Balinese people to use the street for their personal and community space, while the other ethnic group claims that Denpasar, public space belongs to all Indonesian citizens inclusively. The inclusivity and accessibility objectives of Public space are contested. The indigenous ethic community has to consider their public space has certain value because it is related with certain religion and social ceremony in their everyday life, and when equal accessibility being introduced in democratic city naturally it will produce disagreement by indigenous one that prefer exclusivity in relation with place value. As stated by the community leader of Banjar Pedungan that '..the problem of street vendor that most of them from outside Bali are they the persistence to use certain street space but not responsible for its maintenance, especially they often disregard specific Balinese sacred place as their vendor spot preference," .." Thus, the territorial conflict related with ethnic actor differences not only a matter of equal distribution of resources but further more into a justice of right and obligation.

The critical problem of creating justice in community is the difference conception of justice itself. Denpasar 
community considers justice simply into the term of equality fairness. Therefore, it often creates conflict as the distribution of resources is difficult to be always equal in quality and quantity. Cook and Hegtvedt (1983) argue that community integration can be achieved if it follows justice conception with fair exchange, allocation and procedure, but another big challenge comes from the existence of class on community. Common social classification can be based on wealth, power and prestige while indigenous Balinese community classifies their community based on their hereditary caste such as Brahmana, a priest highest caste, Ksatria for noble, Waisya for trader and Sudra, the lowest caste. This community classification has been applied since generation until now and often being utilized as community discrimination because of castle differences. Both common social classification and indigenous one potentially create social conflict because it often affects on an unfair social decision process over distribution of social resources such as the size of individual to use street or other public space. The frequent case of inequality based on social class is expressed on the appropriateness of the community leaders, especially when it is related with potential economic or social resources then the lower social class has a big challenge to compete with the highest one. The social classification also difficult to be minimized as class closely related with personal physical attributes. In modern societies that higher community class is represented by the possession of luxury cars, houses and jewellery it is almost similar with the indigenous one that bring the physical attribute such as first name, dress mode, colour, jewellery, accessories and distinctive architecture of family temple inevitably create another tension inside Balinese community that often creates internal conflict as the treatment and degree of respect to every individual frequently based on caste system. With the fast urban growth in economic, social, political that influence to development of individual creates another complex conflict based on social class, for example, when the lower social castle becomes wealthier than the highest caste then force the equal community respect as the highest caste and in the contrary when the highest caste has lower resources than the lower caste but demands the higher community respect. The tension of Balinese community in social classification is more complicated as its relation with resources and inequality of respect and interaction that can construct a conflict.

Another social conflict factor and also the most sensitive in Denpasar city is social conflict based on religion differences. The case of the terrorist bomb attacks in Bali in 2002 and 2005 that killed more than 200 people has been related with religion conflict even the trial of terrorist has several difficulties as its relation with religion dispute and support from the major and dominant religion group in Indonesia. However, the religion conflict is happened in everyday Denpasar urban life and one of them relate with the contestation over street space for an extension space for religion activities. When Balinese community can claim and block certain street for religion space then the other conflicting religion starts to force their intention to have an equal right to use street space. The street consumption related with religion activities is dealing with large space consumption for vehicle parking, especially for the biggest religion ceremonial date. In this case certain group of communities based on religion commonality often exploit the indigenous Hindu's street religion ceremony frequency to be equal with the others where the Balinese reject this proposition. If there is no coordination and understanding between communities with different religion than conflict is ahead. Religion is not simply a way of communication between human and its creator but often being utilized as social and political tools to mobilize community and directing perception. Dealing with religion conflict in Denpasar city must be carefully justified whether this is pure religion conflict or another social, economic, and political motivation that exploited religion as the efficient and effective way to create social conflict.

Based on the conflict factors (SARA) in Denpasar explained above, it can be summarised here that social conflict over street space contestation come from the lack of social difference appreciation that leads to discrimination of actor or group, which creates injustice of the decision process of material and immaterial value distribution. Denpasar urban community consists of multi ethnic, cultural and religion that should be appreciated equally. Street actor conflict on street space fighting for 'potential' interest space mainly started by individual competition then enlarge to group conflict as commonality solidarity which express social structuration of conflict generated from certain issue's differentiation (European, 2007). Zukin in Madanipour et al. (2001) argues this social differentiation as a factor of social division, create a zone of street actors based on similarities of actor character and sense of group. Social division expressed in physical and social segregation, such as blocking the street accessibility or the presence of street regulator develop the sense of social discrimination from the one who is categorized of the 'owner' of street -public space and the later actor which categorized as intruders (Madanipour, 2010). This segregation as a result of social discrimination inevitably reduces and challenges the street space freedom of access. It became less democratic and contested public space (Madanipour, 1996). Then conflict is a complex disagreement framework involving value, , social, political, cultural, psychological and physical differences, which result individual to structured group dominance of another one (Wetherell and Potter, 1992). Managing these various conflict factors cannot use a singular autonomous top-down 
power and approach but integrated one to maintain social order and conflict problem solving, which need integration of actors as well as the interrelated managing actors, regulators and authorities who act together to shape suitable 'everyday' governance that can determine conflict type and its solutions (European, 2007).

\section{Indigenous management of street space conflict}

How people behave and act on the street is influenced by the internal factor such as personal physiological and physical needs and external factor from social and environmental restriction which made the resolution for conflict focus on people as an individual and as a part of community become main consideration of good democratic local governance in a decentralization system(UNCHS, 2001). Managing community especially the one involved in street use contestation definitely requires good action and manner in governing individual actors with various differences. In this section, the process of managing people on the street by Balinese indigenous people will be discussed especially in balancing traditional embedded values and applying a democratic principle on the street. Based on observation and interview with interrelated actors involved in street space use, the management of street actors and activity horizontal and vertical conflicts have been conducted through avoidance, local force imposition, adjustment, and applying a principle of social integration.

Dealing a conflict, especially when it has already become social structured conflict will be more difficult than avoiding it. Therefore, the first unconscious or conscious action to be taken by individual or group is avoidance to enter or encounter conflicting agency or specific territory. As stated by one of mobile street vendor, Wawan, a meat ball seller that explains the preference of street route and timing based on avoidance to meet specific people that ever harass and ask for 'security' money, and he got beaten when not giving it, as a result he changes the route and also timing with the purpose to avoid specific conflicting group or individual also for his security reason. Other street traders stated the similar thing when they have to select a specific street spot they must carefully study by initial observation, information from another vendor experience or group that specific length, spot or area on Denpasar street space is 'clear' zone from group dominancy, which relates with potential conflict to be avoided. It is also indicated from vendor preference of street space, especially around the potential street such as near city market, school or other public building. The vendor that categorized as a new comer will prefer to select a certain place away from the former vendor ordinary spot. The sense of avoidance of conflict factors often mix comprehended with the discrimination and segregation but for the minority group or the less powerful one, the action of avoidance against domination power is the safest decision to avoid conflict. In this case, the act of avoiding the opportunity of the intruder to enter a specific territory by several indigenous groups can be evaluated as an effort to maintain dominancy and reducing an opportunity for encountering conflicting factor, which also means defining the exact border and segregation (European, 2007) through applying social norm and physical separation between groups by Balinese community can be considered as the initial contribution to maintain social conflict.

Enforcing power by controlling behaviour, accessibility and filtering actors are another way of Balinese community to minimizing conflict in their territory. Balinese often use the term 'Adat' or 'Indigenous custom' in their daily community practice to legalize certain action of enforcing community policy. Another term known by Denpasar urban is 'Dimana bumi diinjak disana langit dijunjung', which means that everyone must obey whatever regulation and policy right on the spot they are standing, another conception of power delegation and authority to smaller scale of space that even in the public space of Denpasar city, it is not following one general rule but more into segregated and compound of small agency regulation with the specific regulators. Community is structured as well as its regulation. Denpasar municipalities consist of four sub-district (Kecamatan) with forty three village (Desa Pakraman), where each village can consist another sub community organization (Banjar), every structure level from the municipality to the smallest group of people on the street has their own regulation which should be coherent or related but it is not easily controlled. This is just an expression how structured the interrelation of urban community really are, but on the other hand express the long distance of municipality authority to directly govern their society. Desa Pakraman and Banjar is an indigenous community organization conception that always being preserved and maintained as it tightly related with inherited and embedded community value, belief and religion. The distinction and the purpose of indigenous community domination to force their certain value and norm is another tension of preserving or deleting custom value in regards of equality principle in a democratic city.

When the powers of local community are not strong enough or resulting from bigger social conflict, then several enforcement or strategies must be adjusted. The adjustment of indigenous action to maintain social harmony is based on their life's principle called Tri Hita Karana, which means maintaining harmonious relation between people with God, 
human and environments. With this principle as the main guidance for other detailed norms and social regulation, then many adjustments have been applied in Balinese community such as decreasing social segregation between indigenous community and migrant by accepting the 'intruder' into community organization structure. While the distinction between local and migrant still obvious from differentiation of resource and power distribution, but at least giving permission for an outsider into Balinese social and physical territory is a good adjustment process for better social collaboration. Other indications of this social collaboration is the use of everyday language, which is indicated on the migrant non Balinese street vendor interaction with the indigenous one. It is found in the field work that in average more than fifty per cent of mobile street vendors comprehends local language with the fastest time to learn it within six months, while around thirty per cent of them can communicate actively using local language. On the other side Balinese, community also behaves similarly with their ability to comprehend other ethnic languages. The interesting points found in this phenomena is that base of conflict is disagreement of human interaction while interaction itself is based on the quality of human communication such as language. Therefore, the openness to learn other languages for better communication is a simple approach for social harmony, when people can share, comprehend and respect others mutually.

The openness of indigenous community to minimize conflict also expressed in the process of profit sharing from street parking to Denpasar municipality. Unlike modern city, that parking can use self-parking meter, In Indonesia this system has not been applied for security and low public law awareness reason with the other important reason that street parking business provides job opportunities for a significant amount of community, especially for the local neighbourhood unemployed people. There are two types of parking system stated by Gede Agustina from Denpasar Public Parking service such as on-street parking, a parking system that uses street traffic space for motor cycle and car parking, and the second type is off-site parking for parking retribution that uses sidewalk and other space beside the street.

Initially, the tension between submitting all parking retribution to local municipality encounter many problems, conflict and controversy by the former parking regulators as it means their livelihood threat, but with good communication and through several bargaining, it comes to collaboration between local community group and municipality for parking retribution sharing. Sixty per cent for community and forty per cent for municipality proportion has been agreed as the balance proportion of parking retribution sharing. Although municipality has fewer amounts compared to the expected public space revenue, it offers a stage when all the other competing activity be cooperated with minimum conflict. People livelihood still can be preserved not eliminated, local neighbourhood still can work in their home range area; local community still have power to coordinate their own community member and maintain their indigenous power and respect, while municipality still can coordinate street actor efficient and effectively as being fully supported by local community. In summary, conflict over street space, disputing its economic value can be solved by sharing it profit, while it seems unequal but with agreement between all disputed actors. Duncan in Kellett (2006) argues that community cohesion can be achieved through mechanism, structure and composition of distribution value and power, surplus and opportunity in that create stable harmonious community participation integrated with local municipality (Beard and Dasgupta, 2006).

Community integration is both product and process of conflict management related with actor identity and distribution of economic, social, political resources, value and power. The previous interaction between Denpasar municipality, indigenous community and street actors define that there is a good cooperation between all urban agency that can accommodate and assimilate needs and interest between them to create integration. To discuss further that the sixty-forty agreement is not merely an economic generated factor but also relates with the adjustment of social structuration. Indigenous that initially self-government and exclusive community restructuring themselves with allowing external actor such as municipality and other street actor to be embedded to their inherited indigenous structure. It shows that, dealing with street contestation of space both municipality and indigenous organization restructure their direction and distribution of power to combine and integrate with others. When previously separated and autonomous based on their own comprehension of legitimation into something new, transformed, integrated and assimilated one. However , this organization restructuration for negotiating conflicting agency is not enough, as the agreement itself must be in a written form with all detailed item agreed by conflicting actors who form new consensus as based of conflict management mechanism. This new community consensus is a form of defocusing conflict to integration which means when the consensus has not created, the conflicting agency will focus their action to segregation and differentiation but when consensus is created then focus will be directed to the act of integration and conflict reduction as argues by Ross (1993) as psycocultural theory .

The frequent of community gathering for both discussing community problems in 'Bale Banjar' community meeting place or working together 'Ngayah' community social work in specific place and street such as cleaning and 
decorating before any community occasion shows that Balinese people has strong social capital which shown by their collective action. This collective community activity shows that the class differences between community member is being overlooked and replaced with the democratic communication where every member have equal obligation, voice and right to develop community. The recent positive of Balinese community transformation is their openness to new member of the original 'indigenous' one. Beside the rapid urban community mobilization that even the former community can relocate to other places for various reasons that inevitably restructure the composition of community inside 'Desa Pakraman ' territory. When the quantity is decreasing it open the 'new' member to enter the group, including migrant as a connection of community coordination and reconciliation(Madanipour, 2010). While the distinction still exist but the limitation of member sometimes successful to create a new compound Balinese community with no absolute indigenous domination. With this multi various actor partnership, the occupation and maintenance of space inside community territory become common responsibility which directly greater the sense of community, ownership and place attachment (Madanipour, 2004).

Furthermore, Madanipour (2004) suggests that social difference reconciliation from the outsider actors and the richness indigenous community will be initially developed by economic relation then followed by another social and political integration with the condition that transparency, rule of law and democratic principal being applied. Therefore the presence of local regulation and norm such as Awig-awig and Perarem in Balinese community is not merely a social constraint that enforcing indigenous domination but should be considered as a tool for avoiding community conflict and problem (Kellett, 2006). It is reflected on Denpasar street that have been considered as another 'home of community', a place for social relationship that strengthen the relation between various street user with many difference's background (Kellett, 2008).

\section{Conclusion}

Social conflict is a unique social phenomena that has their own character in urban society, which determined by the uniqueness of difference's factors and the quality of 'SARA' ( social conflict based on tribes, religion, race, and social class differences) management and distribution of street actor's needs, rights, interests, powers and material and immaterial resources. The existence of conflict produces both negative and positive impacts that gradually transform the structure of community to adapt and adjust the recent development of urban growth. With a more inclusive process, it produces and reproduces a new form of social, community and neighbourhood structuration. Balinese community indigenous norm equipped with more detailed-adjusted rule, shows their creative 'responsibility gap' concept (European, 2007) as their key of community governance. A street in Denpasar is a part of Balinese economy, social and cultural space embedded with traditional and religion value, which made as sense of community 'ownership and well being' (Madanipour, 2004:285) which is still allowing flexibility of street occupation for various actors and activity redefining what the meaning of street as 'Balinese home of community' space.

\section{References}

Beard, V. A. \& Dasgupta, A. 2006. Collective action and community-driven development in rural and urban Indonesia. Urban Studies, 43, 1451-1468.

Cook, K. S. \& Hegtvedt, K. A. 1983. Distributive Justice, Equity, And Equality. Annual Review of Sociology, 9, 217-241.

European, C. 2007. Neighbourhood governance - capacity for social integration Luxembourg: European Communities.

Fink, C. F. 1968. Some conceptual difficulties in the theory of social conflict. Journal of conflict resolution, 412-460.

Gebrewold-Tochalo, B. 2009. Anatomy of Violence: Understanding the Systems of Conflict and Violence in Africa, Ashgate.

Geertz, C. 1993. The Interpretation of Cultures: Selected Essays, FontanaPress.

Kellett, P. B., W. 2006. Reinforcing traditional values: Social, spatial and economic interactions in an Indonesian Kampung. Open House International, 31, 58-66.

Kellett, R. D. P. 2008. Housing and home-making in low-income urban settlements: Sri Lanka and Colombia. House and the Built Environment 23:53-70

Luhmann, N. 1995. Social Systems, Stanford University Press.

Madanipour, A. 1996. Design of urban space: an inquiry into a socio-spatial process, Wiley.

Madanipour, A. 2004. Marginal public spaces in European cities. Journal of Urban Design, 9, 267-286.

Madanipour, A. 2007. Designing the City of Reason: Foundations and Frameworks in Urban Design Theory, Taylor \& Francis.

Madanipour, A. 2010. Whose public space?: international case studies in urban design and development, Routledge.

Madanipour, A., Hull, A. \& Healey, P. 2001. The Governance of Place: Space and Planning Processes, Ashgate.

Ritzer, G. 2005. Encyclopedia of social theory, Sage Publications. 
Sopandi, A. 2012. Kebijakan Pemerintah Daerah Terhadap Potensi Integrasi Dan Potensi Konflik Keagamaan Di Daerah UrbanStudi Kasus: Identifikasi Pola dan Strategi Peningkatan Integrasi Masyarakat di Kota Bekasi. Jurnal FISIP: Madani, 4.

UNCHS 2001. Cities in a Globalizing World : Global Report on Human Settlements, London, Earthscan.

Wetherell, M. \& Potter, J. 1992. Mapping the language of racism: discourse and the legitimation of exploitation, Harvester Wheatsheaf. 